\title{
A study of the Effect of Ghrelin on the Regulation of Pancreatic Exocrine Secretion in Male Albino Rats
}

\author{
Romysa A. El-Sherbeny and Mahmoud A. El-Gharieb \\ Department of Physiology, Tanta University
}

\begin{abstract}
The present work was done to investigate the role of ghrelin in the regulation of pancreatic volume and protein secretion in anaesthetized male albino rats. The rats were divided into 4 equal groups: First group Is the control group. Second group: Pancreatic secretion was stimulated by infusion of wheat germ lectin, which is known to be a stimulus of cholicystokinin hormone release, preceded by ghrelin infusion and continued for one hour, this procedure was performed before and after acute subdiaphragmatic vagotomy. Third group: was infused by 2-D-glucose, which acts as central vagal stimulant, preceded by ghrelin infusion and continued for one hour Fourth group: was infused by bethanechol, which is a cholinergic receptor agonist, preceded by ghrelin infusion and continued for one hour. Then the pancreatic secretion was collected after anaesthetizing male albino rat, through a cannula inserted in the common bile duct. The results showed significant increase of the protein content by wheat germ lectin infusion, through stimulation of cholicystokinin which stimulated pancreatic secretion, Ghrelin caused significant inhibition of protein secretion and this inhibition was continued after acute subdiaphragmatic vagotomy, Ghrelin also caused significant inhibition of the pancreatic protein secretion, which caused by central stimulation of vagus nerve by 2-D-glucose infusion. Also, ghrelin showed significant inhibition of the pancreatic protein secretion which caused by bethanechol, that acting as a muscarinic receptor agonist. It is concluded that ghrelin is a potent inhibitor of pancreatic exocrine protein secretion and the mechanism of its action may be directed at the level of the intra pancreatic neurotransmission.
\end{abstract}

\section{INTRODUCTION}

Ghrelin is a natural endogenous legend for growth hormone secretagogue receptors which present in the brain, which was isolated from rat stomach $^{(\mathbf{1})}$. It was identified in some endocrine cells of the gastrointestinal tract ${ }^{(2)}$. Ghrelin immunoreactivity has been detected in the hypothalamic arcuate nucleus ${ }^{(\mathbf{1})}$. Moreover, the finding that growth hormone secretagogue receptors are present in several brain areas and in peripheral tissue ${ }^{(3)}$, which indicates the regulatory role for this peptide in many biological activities. Previous studies have shown that ghrelin stimulated growth hormone release and food intake in rodents after either systemic or central administration ${ }^{(\mathbf{4})}$. More interesting finding that stomach ghrelin as well as plasma ghrelin levels were increased during acute nutrient restriction ${ }^{(5)}$. It was reported that ghrelin was one of many brain peptides which influence feeding behavior, ghrelin can also trigger 
gastric secretion ${ }^{(6)}$ and motor responses ${ }^{(7)}$. Although ghrelin has been reported to stimulate gastric acid secretion in anesthetized rats ${ }^{(6,7)}$, it was demonstrated that the central administration of ghrelin effectively inhibited gastric acid secretion in conscious rats $^{(8)}$.

Pancreatic exocrine secretion is controlled physiologically by both the autonomic nervous system and a number of brain gut peptides. Among these peptides cholicystokinin (CCK), secretin, cocaine and amphetamine that regulated transcript peptide and stimulated pancreatic secretion ${ }^{(9)}$, whereas neuropeptide $\mathrm{Y}$ and somatostatin served as inhibitors ${ }^{(\mathbf{1 0})}$. Cholicystokinin (CCK) is an established gastrointestinal hormone that stimulates gall bladder contraction. Subsequently CCK has been found to regulated pancreatic exocrine and endocrine secretion, gastrointestinal motility, pancreatic growth, intestinal blood flow and satiety ${ }^{(11)}$.

The normal diet contains many lectins $^{(\mathbf{1 2})}$. They are generally heat labile, but considerable amounts remain after cooking. Once lectin ingested, its activity was largely persists during its passage through the gastrointestinal tract ${ }^{(12)}$. The mechanism of action of lectin is performed by binding to N-acetyl Dgalactosamine that tends to stimulate intestinal cells ${ }^{(\mathbf{1 3})}$. Wheat germ (tricum vulgris) lectin binds to n-acetyl-dglucosamine and causes calcium dependent stimulation of enterocytes $^{(\mathbf{1 4 )}}$. This is an interesting, because elevation of intracellular calcium can caused increase of CCK secretion $^{(\mathbf{1 5})}$.
The present study was performed to examine the effect of ghrelin on the volume and protein content(amylase) of pancreatic exocrine secretion and its mechanism of action in anaesthetized male albino rats.

\section{MATERIALS \& METHODS}

24 male albino rats weighing 200 $250 \mathrm{gm}$ were housed in single cages that had wire net 60 inches. Before the experiments all rats were fasted for 24 hours, but had free access to tap water. The rats were divided into four equal groups each containing sex rats: Group (1): control group in which the rats were administrated by saline infusion in the common bile duct.

Group (2): Lectin stimulation group, were administrated wheat germ lectin CCK stimulant) for 15 minutes. The rats were infused by synthetic rat ghrelin that started 15 minutes before wheat germ lectin and continued for the rest of the experiment. Acute sub diaphragmatic vagotomy was done with continuous infusion of ghrelin for the rest of the experiment.

Group (3): 2-D-glucose stimulation group: In which the rats were administrated by 2-D-glucose(central vagal stimulant) as a single bolus. Ghrelin infusion was started 15 minutes before 2-D-glucose infusion and continued for the rest of the experiment.

Group (4): bethanechol stimulation group: The rats were administrated by bethanechol (muscarinic stimulant) as a continuous intravenous infusion. Ghrelin infusion was started 15 minutes before bethanechol infusion 
and continued for the rest of the experiment.

On the morning of the experiment, the rats were anaesthetized with intramuscular injection of ketamine and xylazine (sigma) in a dose of $87,13 \mathrm{mg} / \mathrm{kg}$ body weight ${ }^{(16)}$, supplemental doses were used every 2 hours to maintain adequate anesthesia. An intravenous cannula was placed into the right external jugular vein for infusion of $0.9 \% \mathrm{NaCL}(1 \mathrm{ml} / \mathrm{min})$ with other chemicals. Through an upper midline labarotomy, the duodenum was elevated and the bile duct isolated as it entered the posterior duodenum. Through a small incision, a polyethylene cannula (PE (10) sigma) was introduced into the common bile duct and was fixed in place with fine silk suture. A second polyethylene cannula (PE (50) sigma) was placed into the duodenum ${ }^{(\mathbf{1 6})}$. The abdominal wound was covered with a saline moist gauze. At the end of the experiments, animals were killed by cervical dislocation.

1- Pancreatic secretion study: The pancreatic juice was collected for one hour to allow stabilization of flow after surgical manipulation. The pancreatic secretions were collected over 30 minutes. The volume was recorded and aliquots were assayed for protein content (17)

2- Study of the effect of ghrelin and wheat germ lectin on pancreatic secretion: Wheat germ lectin (90 $\mathrm{mg} / \mathrm{kg} \mathrm{BW})^{(\mathbf{1 8})}$ from Sigma was infused into the duodenum in a total volume of $5 \mathrm{ml}$ over 15 minutes. Infusion of synthetic rat ghrelin (1-2 n mol/kg/hours) ${ }^{(16)}$ from (Phoenix pharmaceuticals) was begun 15 minutes before wheat germ lectin administration and continued for the rest of the experiment .Ghrelin infusion was continued after acute sub diaphragmatic vagotomy

3- Study of the effect of ghrelin and 2-D-ghucose (2-DG) on pancreatic secretion: $2-\mathrm{DG}$ is centrally acting vagal stimulant ${ }^{(19)}$. 2-DG $(75 \mathrm{mg} / \mathrm{kg})^{\mathbf{( 1 6 )}}$ from Sigma was dissolved in saline and administered as a bolus intravenous injection. Ghrelin infusion (1-2 n $\mathrm{mol} / \mathrm{kg} /$ hour) was started 15 minutes before 2-DG injection and continued for the rest of experiment (16).

4- Study of the effect of ghrelin and bethanechol on pancreatic secretion: Bethanechol is a cholinergic receptor agonist. Bethanechol (3 $\mathrm{mg} / \mathrm{kg}){ }^{(16)}$ from Sigma was dissolved in saline and administered as a continuous intravenous infusion. Ghrelin infusion (1-2 $\mathrm{n} \mathrm{mol} / \mathrm{kg} /$ hour) was started 15 minutes before the bethanechol infusion and continued for the rest of the experiment.

\section{Statistical analysis:}

Data were expressed as multiples of basal secretion. The results are expressed as means \pm SD. a two-way analysis of variance (ANOVA) was used to analyze differences between treatment groups. Student's unpaired ttest was used to analyze data from integrated protein secretion and volume differences were considered significant when $\mathrm{P}$ values were less than 0.05 . 


\section{RESULTS}

The results of the present work showed in table (1):

1- Effects of ghrelin and wheat germ lectin infusion on pancreatic secretion: Wheat germ lectin infusion resulted in a significant increase in both volume and protein content of the pancreatic secretion $(\mathrm{P}<0.05)$. Ghrelin infused 15 minutes before wheat germ lectin showed non significant change in volume and significant reduction in protein content in relation to basal secretion $(\mathrm{P}<0.05)$. Acute sub diaphragmatic vagotomy at the same time of ghrelin infusion showed non significant change in volume and significant reduction of protein content $(\mathrm{P}<0.05)$. There was significant reduction of protein content after vagotomy by ghrelin and lectin $(\mathrm{P}<0.05)$ Fig 1 .
2-Effects of ghrelin and 2-DG infusion on pancreatic secretion: 2-DG infusion caused significant increase in volume and protein content of the pancreatic secretion in relation to basal secretion $(\mathrm{P}<0.05)$. Ghrelin infusion started 15 minutes before 2-DG showed a significant reduction in protein content and non significant change in relation to 2-DG infused rats $(\mathrm{P}<0.05)$ Fig2 .

3-Effects of ghrelin and bethanechol infusion on pancreatic secretion: Bethanechol infusion showed significant increase in both volume and protein content in relation to control $(\mathrm{P}<0.05)$. Ghrelin infusion started with bethanechol and continued for 15 minutes showed non significant change in volume and significant reduction in protein content $(\mathrm{p}<0.05)$ Fig3.

Table (1): Effects of ghrelin on pancreatic secretion volume (ml/15min) and protein (amylase) (U/15 min) stimulated by wheat germ lectin, 2-D-glucose and bethanechol in male albino rats

\begin{tabular}{|l|l|l|}
\hline Groups ( Mean \pm SD 6rats) & $\begin{array}{l}\text { Protein(Amylase) } \\
\text { U/15 min }\end{array}$ & $\begin{array}{l}\text { Volume } \\
\text { ml/15min }\end{array}$ \\
\hline (1) Control group & $3.26 \pm 0.32$ & $0.3 \pm 0.03$ \\
\hline (2) Lectin administrated group & $16.2 \pm 0.91^{*}$ & $0.34 \pm 0.03^{*}$ \\
\hline (3) Lectin and Ghrelin administrated group & $\begin{array}{l}11.76 \pm 68^{*} \\
\mathrm{~T} 2=*\end{array}$ & $0.31 \pm 0.01$ \\
\hline $\begin{array}{l}\text { (4) Acute vagotomy and ghrelin } \\
\text { administrated group }\end{array}$ & $5.24 \pm 0.27^{*}$ & $0.32 \pm 0.01$ \\
\hline (5) 2-DG administrated group & $4.85 \pm 0.41^{*}$ & $0.36 \pm 0.01^{*}$ \\
\hline (6) 2-DG and ghrelin administrated group & $\begin{array}{l}2.19 \pm 0.16^{*} \\
\mathrm{~T} 2=*\end{array}$ & $0.34 \pm 0.01^{*}$ \\
\hline (7) Bethanechol administrated group & $5.38 \pm 0.28^{*}$ & $0.35 \pm 0.02^{*}$ \\
\hline (8) Bethanechol and ghrelin administrated & $2.37 \pm 0.2^{*}$ & $0.35 \pm 0.01^{*}$ \\
group & $\mathrm{T} 2=*$ & \\
\hline
\end{tabular}

$*=$ Significant $P<0.05$. 


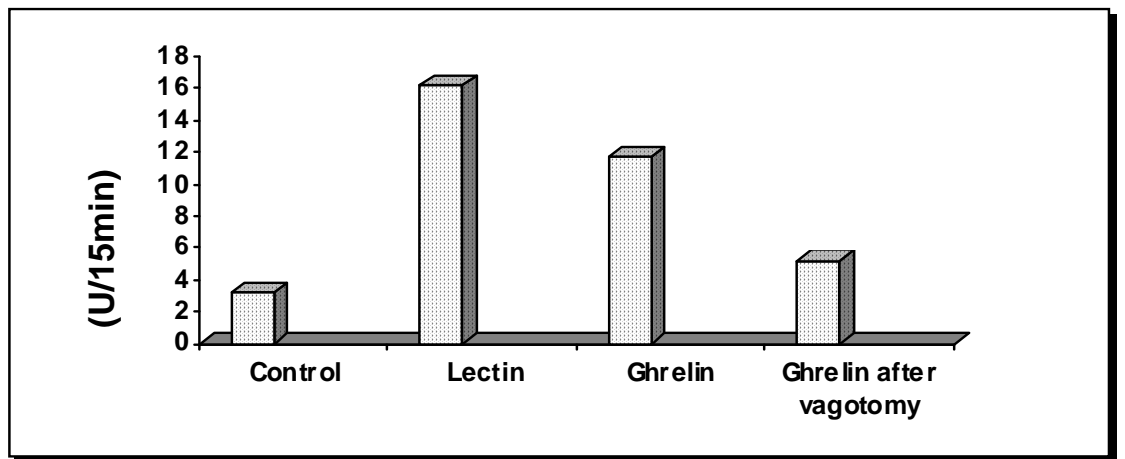

Fig. (1): Effect of ghrelin and wheat germ lectin before and after acute vagotomy on pancreatic protein secretion (U/15min) in male albino rats.

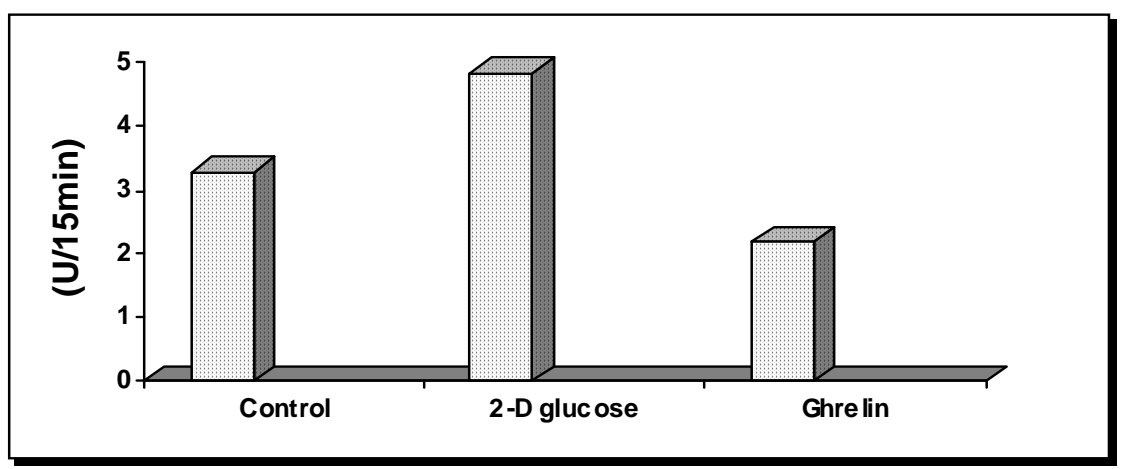

Fig. (2): Effect of ghrelin and 2-D-glucose on pancreatic protein secretion (U/15min) in male albino rats

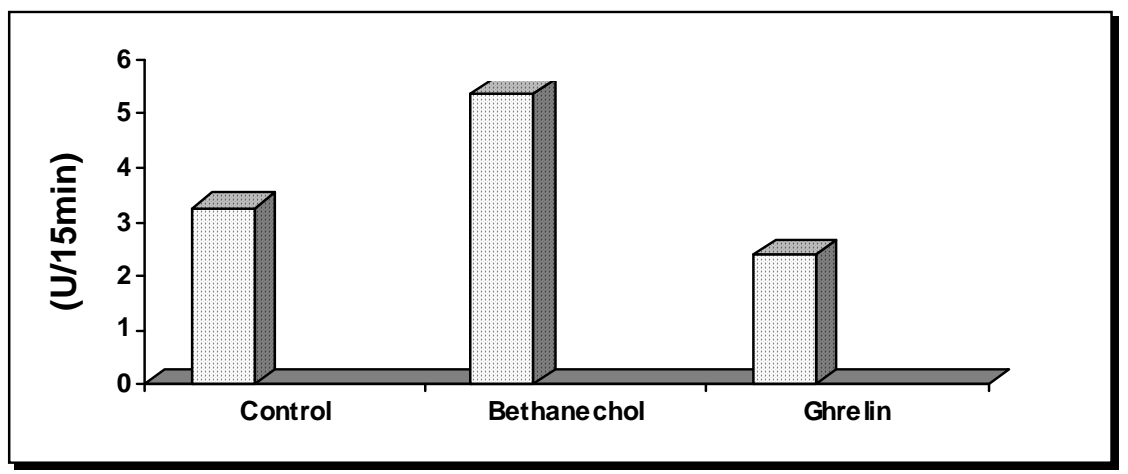

Fig. (3): Effect of ghrelin and bethanechol on pancreatic protein secretion (U/15min) in male albino rats. 


\section{DISCUSSION}

Ghrelin is a novel 28 amino acid peptide secreted form the endocrine cells of gastric mucosa ${ }^{(20)}$. It is an endogenous legend for the growth hormone secretagogue receptor, which has been demonstrated in both central nervous system and peripheral tissues (21). Where as ghrelin was initially identified as, a growth hormone releasing peptide with a wide range of actions have been reported. The results of the present work studied the mechanism of the inhibitory effect of ghrelin on exocrine pancreatic volume and protein secretion. The results showed that ghrelin significantly inhibited the increase of pancreatic secretion that caused by lectin infusion which stimulated CCK release and caused an increase of pancreatic secretion. Moreover ghrelin inhibited CCK-stimulation of the pancreatic secretion after acute subdiaphragmatic vagotomy. In addition ghrelin inhibited pancreatic secretion stimulated by 2-DG infusion and decreased that of bethanechol stimulation.

Expression of ghrelin and its related receptors of growth hormone secretagogue receptor, which caused stimulation of food intake and subsequent body weight gain, have been demonstrated in rats administered by ghrelin either centrally or peripherally ${ }^{(22,23)}$. In the gastrointestinal tract, ghrelin has been demonstrated to regulate gastric acid secretion and gastric motility (24). Ghrelin may be involved in the regulation of digestive process which was supported by the observation that ghrelin producing cells correspond to
$\mathrm{X} / \mathrm{A}$ like endocrine cells in gastrointestinal tract that including stomach, small intestine and pancreas (1). The pancreas has been demonstrated to express growth hormone secretagogue like receptor $^{(25)}$.

Regulation of pancreatic exocrine secretion occurs at multiple levels including the central nervous system. Pancreatic innervations (intra pancreatic neurons) that is supplied to the receptors, which present on pancreatic acinar cells ${ }^{(9)}$.

The mechanism by which ghrelin inhibited pancreatic protein output, may be by a direct effect, because ghrelin did not have any effect on pancreatic acini exposed to the peptide in virtue ${ }^{(\mathbf{1 6})}$. Also it may be suggested that, the inhibitory actions of ghrelin are not mediated by its direct action on the acinar cells. This indirect inhibitory action on pancreatic secretion has been reported for neuropeptide $\mathrm{Y}^{\mathbf{( 2 5 )}}$. Similar to neuropeptide $Y$, ghrelin appears to act on the intrapancreatic neurons to inhibit protein secretion ${ }^{(\mathbf{1 9})}$. In addition, fat hydrolysis is essential to induce the effects of ghrelin and neuropeptide $\mathrm{Y}$, this occur through generation of long chain fatty acids (LCF). Furthermore LCF stimulated plasma $\mathrm{CCK}$ release, so this is suggesting that $\mathrm{CCK}$ is a mediator of ghrelin inhibitory effect. Also CCK-1 receptor antagonists abolish the effect of both ghrelin and neuropeptide Y (23). It was suggested that ghrelin may have an action within the central nervous system, ghrelin upregulates the role of neuropeptide $\mathrm{Y}$ and related protein genes in hypothalamus ${ }^{(24)}$ and also $m$ RNA is present in dorsomotor 
nucleus of the vagus ${ }^{(23)}$. Moreover stimulation of gastric secretion by ghrelin administrated by intracerebroventricular injection is mediated through direct central activation of the central vagal mechanism $^{(23)}$. Also, ghrelin replacement partially reversed the gastrectomy that induced reduction in body weight ${ }^{(25)}$. The results of present study supported the idea that detected that the actions of ghrelin on pancreatic secretion are directed at the level of intrapancreatic neuron (26). Ghrelin caused reduction of pancreatic protein secretion stimulated by 2-Dglucose, which is a centrally acting vagal stimulant, but partially caused inhibition of the pancreatic protein secretion which stimulated by lectin, which stimulated CCK release, 2-DG or bethanechol. Also vagotomy failed to reverse the inhibitory effects of ghrelin on CCK stimulation of pancreatic secretion. Moreover it was observed that ghrelin resulted in decrease of amylase release stimulated by depolarizing concentration of KL in pancreatic lobules ${ }^{(16)}$.

Conclusions:

The present study has demonstrated that, ghrelin is a potent inhibitor of pancreatic exocrine secretion in male albino rats. The action of ghrelin is direct and it may affect intra pancreatic neurotransmission as a mechanism of action.

\section{REFERENCES}

1- Kojima M, Hosoda H, Date Y, Nakazato $M$, Matsuo $H$, Kangawa K. Ghrelin is a growthhormone-releasing acylated peptide from stomach. Nature. 1999 Dec 9; 402(6762):656-60.

2- Date Y, Kojima M, Hosoda H, Sawaguchi A, Mondal MS, Suganuma T, Matsukura S, Kangawa $K$, Nakazato $M$. Ghrelin, a novel growth hormonereleasing acylated peptide, is synthesized in a distinct endocrine cell type in the gastrointestinal tracts of rats and humans. Endocrinology. 2000 Nov; 141(11):4255-61.

3- Guan XM, Yu H, Palyha OC, McKee KK, Feighner SD, Sirinathsinghji DJ, Smith RG, Van Der Ploeg LH, Howard AD. Distribution of mRNA encoding the growth hormone secretagogue receptor in brain and peripheral tissues. Brain Res Mol Brain Res. 1997 Aug; 48(1):23-9.

4- Seoane LM, Tovar S, Baldelli R, Arvat E, Ghigo E, Casanueva FF, Dieguez C. Ghrelin elicits a marked stimulatory effect on $\mathrm{GH}$ secretion in freely-moving rats. Eur J Endocrinol. 2000 Nov; 143(5):R7-9.

5- Lee HM, Wang G, Englander EW, Kojima M, Greeley GH. Ghrelin, a new gastrointestinal endocrine peptide that stimulates insulin secretion: enteric distribution, ontogeny, influence of endocrine, and dietary manipulations. Endocrinology. 2002 Jan;143(1):185-90.

6- Masuda Y, Tanaka T, Inomata N, Ohnuma N, Tanaka S, Itoh Z, Hosoda H, Kojima M, Kangawa K. Ghrelin stimulates gastric acid secretion and motility 
in rats. Biochem Biophys Res Commun. 2000 Oct 5; 276(3): 905-8.

7- Date Y, Nakazato M, Murakami N, Kojima M, Kangawa $\mathrm{K}$, Matsukura $\mathrm{S}$. Ghrelin acts in the central nervous system to stimulate gastric acid secretion. Biochem Biophys Res Commun. 2001 Jan 26; 280(3):904-7.

8- Sibilia V, Pagani F, Guidobono F, Locatelli V, Torsello A, Deghenghi R, Netti C. Evidence for a central inhibitory role of growth hormone secretagogues and ghrelin on gastric acid secretion in conscious rats. Neuroendocrinology. 2002 Feb;75(2):92-7.

9- Cowles RA, Segura BJ, Mulholland MW. Stimulation of rat pancreatic exocrine secretion by cocaine- and amphetamineregulated transcript peptide. Regul Pept. 2001 May 5; 99 (1):61-8.

10- Chey WY. Hormonal control of pancreatic exocrine secretion in the pancreas. Biology, Pathobiology and Disease, $2^{\text {nd }} \mathrm{ed}$, ed. GOVLW pp 1993; 403-424. Raven press. New York.

11- Bouras EP, Misukonis MA, Liddle RA. Role of calcium in monitor peptide-stimulated cholecystokinin release from perfused intestinal cells. Am J Physiol. 1992 May;262(5 Pt 1):G791-6.

12- Ryder SD, Smith JA, Rhodes JM. Peanut lectin: a mitogen for normal human colonic epithelium and human HT29 colorectal cancer cells. J Natl Cancer Inst.
1992 Sep 16;84(18):1410-6.

13- Koninkx JF, Brown DS, Kok W, Hendriks HG, Pusztai A, Bardocz S. Polyamine metabolism of enterocyte-like Caco-2 cells after exposure to Phaseolus vulgaris lectin. Gut. 1996 Jan; 38(1):47-52.

14- Sjolander $A$ and Magnusson KE. Effects of wheat germ agglutinin on the cellular content of filamentous actin in intestinal cells. J Cell Physiol, 1998; 134: 473-478.

15- Mangel AW, Scott L, Liddle RA. Depolarization-stimulated cholecystokinin secretion is mediated by L-type calcium channels in STC-1 cells. Am J Physiol. 1996 Feb; 270(2 Pt 1):G287-90.

16- Zhang W, Chen M, Chen Y, Bradley J, Segura $I$ and Micheel W. Inhibition of pancreatic secretion by ghrelin in the rat. Ann Arbor, 2001; 48: 109-331.

17- Juda WJ. Methods in immunogematology Duram NC: Montgomery Scientific Publications. 1994.

18- Pusztai A, Grant G, Baintner $\mathrm{K}$, Bardocz S, Herzig KH, Folsch UR, Nustede R. Orally administered lectins induce release of CCK from the duodenum and the growth of the pancreas which is blocked by CCK-A receptor antagonists. Regulatory Peptides, 1996; 64(1): pp. 156-156(1).

19- Putnam WS, Liddle RA, Williams JA. Inhibitory regulation of rat exocrine pancreas by peptide YY and 
pancreatic polypeptide. Am J Physiol. 1989 Apr; 256 (4 Pt 1): G698-703.

20- Papotti M, Ghè $C$, Cassoni $P$, Catapano $F$, Deghenghi $R$, Ghigo E, Muccioli G. Growth hormone secretagogue binding sites in peripheral human tissues. J Clin Endocrinol Metab. 2000 Oct; 85(10):3803-7.

21- Mori K, Yoshimoto A, Takaya $\mathbf{K}$, Hosoda $\mathbf{K}$, Ariyasu $\mathbf{H}$, Yahata K, Mukoyama M, Sugawara A, Hosoda $\mathbf{H}$, Kojima M, Kangawa K, Nakao K. Kidney produces a novel acylated peptide, ghrelin. FEBS Lett. 2000 Dec 15; 486(3):213-6.

22- Nakazato $M$, Murakami N, Date Y, Kojima M, Matsuo $H$, Kangawa K, Matsukura S. A role for ghrelin in the central regulation of feeding. Nature. 2001 Jan 11; 409 (6817):194-8.

23- Degen L, Drewe J, Piccoli F, Gräni K, Oesch S, Bunea R, D'Amato M, Beglinger C. Effect of CCK-1 receptor blockade on ghrelin and PYY secretion in men. Am J Physiol Regul Integr Comp Physiol. 2007 Apr; 292(4): R1391-9.

24- Mulholland MW, Lally K, Taborsky GJ. Inhibition of rat pancreatic exocrine secretion by neuropeptide Y: studies in vivo and in vitro. Pancreas. $1991 \mathrm{Jul}$; 6(4):433-40.

25- Dornonville de la Cour $C$, Lindqvist A, Egecioglu E, Tung YC, Surve V, Ohlsson C, Jansson JO, ErlansonAlbertsson C, Dickson SL, Håkanson R. Ghrelin treatment reverses the reduction in weight gain and body fat in gastrectomised mice. Gut. 2005 Jul; 54(7):907-13.

26- Mundinger TO, Cummings DE, Taborsky GJ. Direct stimulation of ghrelin secretion by sympathetic nerves. Endocrinology. 2006 Jun; 147 (6): 2893-901. 


\title{
دراسة عن تأثير الجريلين على تنظيم افراز العصارة البنكرياسية في ذكور الفئران البيضاء النزاء
}

\author{
روميساء على الثربينى ومحمود عبد الحميد الغريب
}

قسم الفسيولوجى كلية الطبر الطب- جامعة طنطا

يهدف هذا البحث إلى دراسة دور الجريلين في افراز العصارة البنكرياسية و ميكانيكية تنظيم إفراز

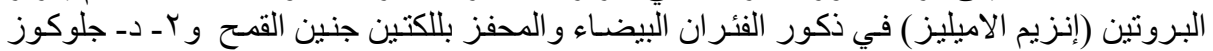

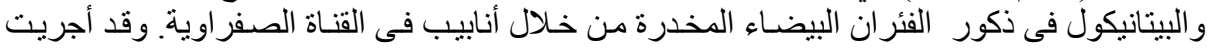

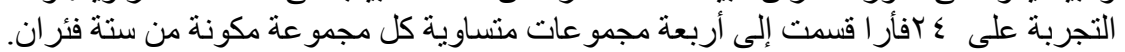

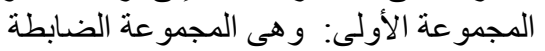

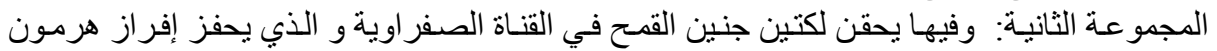

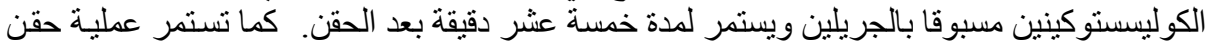

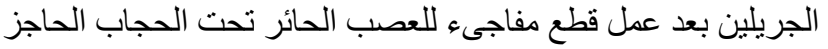

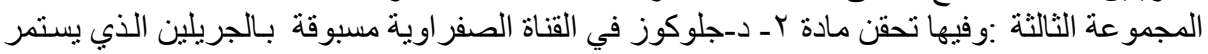

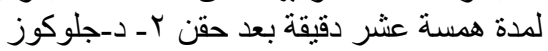

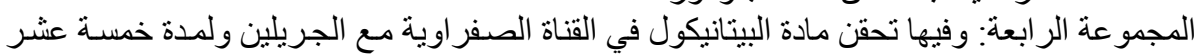

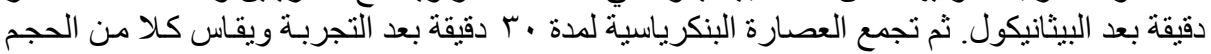

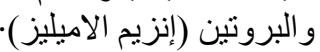

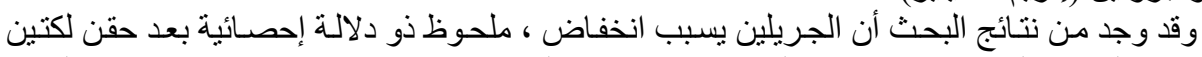

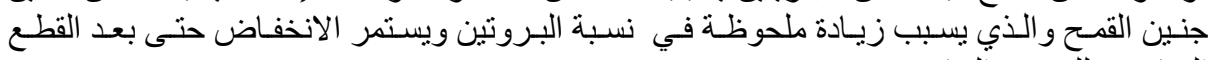
المفاجىء للعصب ألحائر.

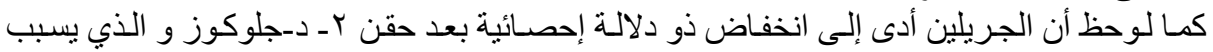

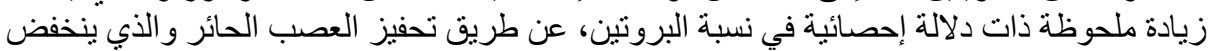

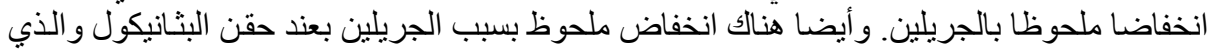

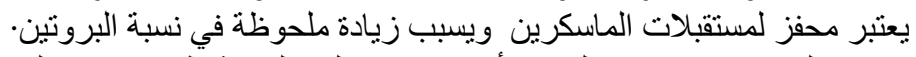

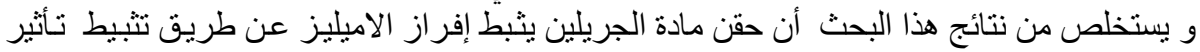

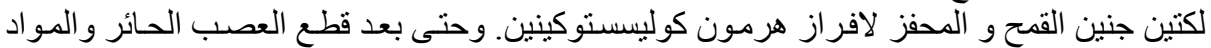

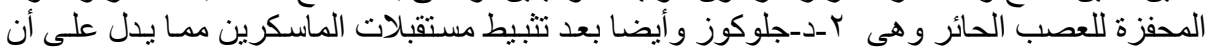

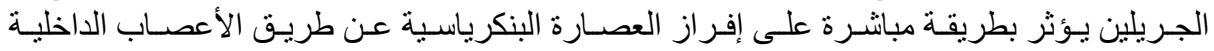

